\title{
Preference of Rural Youth Livelihood in Indonesia Rural Areas and Its Factors
}

\author{
Anisa Aprilia ${ }^{*}$, Condro Puspo Nugroho ${ }^{2}$, Rini Mutisari ${ }^{3}$ \\ Socio Economic Department, Agriculture Faculty, Brawijaya University, Jl. Veteran, Malang 65145, \\ Indonesia
}

Received: 10 May 2019; Revised: 22 November 2019; Accepted: 22 November 2019

\begin{abstract}
Indonesia is facing serious problem of unemployment in rural areas while in agricultural sector, there is lack of labour availability. This research discusses issue between livelihood choices and their determinant factors of rural youth in East Java, Indonesia. The 200 survey data was analysed by multinomial logit for measuring response probabilities of alternative livelihoods which consist of agricultural jobs, nonagricultural employment, non-farm entrepreneur, and urban employment. The outcome of the research is that education of youth has consistently positive and significant correlation with livelihood option which is outside of agricultural sector. The more academic achievements that respondents get, the more reasonable their expectation of success in outside farming relative to agriculture. On the other hand, the larger land holding that their parents have, the lower possibility in choosing a livelihood outside of agriculture over farming. Therefore, it implies that better land access will encourages youth to approach agricultural works.
\end{abstract}

Keywords: livelihood choice; rural youth; rural livelihood

\section{How to Cite:}

Aprilia, A., Nugroho, C. P., \& Mutisari, R. (2019). Preference of Rural Youth Livelihood in Indonesia Rural Areas and Its Factors. HABITAT, 30(3), 88-95. https://doi.org/10.21776/ub.habitat.2019.030.3.11

\section{Introduction}

Agriculture remains the top economic livelihood for most rural households, while in speedily developing and transforming regions, the effective agricultural practices can bring through and sustain rural livelihoods which depend on the natural resources (Dzanku, 2015; Gregoire, 2011; Smith, Hudson, \& Schreckenberg, 2017; Tang, Bennett, Xu, \& Li, 2013). Moreover, organic farming can ensure alternative livelihoods are stable and sustainable, especially in situations where available land can be managed optimally (Qiao et al., 2018). But, the labor in farming is crucial factor in livelihood choice, especially rural youth who is the future generation in farming system. A heavy shortage in agricultural labor has produced in a decline grain and crop acreage and also the efficiency of farm utilization (Qian, Wang, \& Zheng, 2016).

In Indonesia, labor absorption in the agricultural sector in 2010 was around 38.69 million workers or around $35.76 \%$ of the total

${ }^{*}$ Correspondence Author

E-mail: jangnisa@gmail.com employment. In 2014 employment decreased to 35.76 million workers or $30.27 \%$. Data on employment in the agricultural sector only comes from the activities of the primary agricultural sector, not including the secondary and tertiary sectors of the agribusiness system and business. The main problem of employment in the agricultural sector, namely the existence of the age of productive labor and the level of education. Based on Statistics Indonesia data, the average growth of labor in the agricultural sector experienced an increase of $0.64 \%$ per year in the period 2005-2009, and a decrease of $1.49 \%$ per year between 2010 and 2014. The decline in the growth of the largest workforce is precisely in the youth age group, which is between the ages of 15 to 29 years with an average reduction of $3.41 \%$ per year (Ministry of Agriculture Republic Indonesia, 2015).

Employment in agriculture is an indicator of sector development and provides guidance on sustainability and farming youth, responsive to new development efforts and entrepreneurial capacity (Chiritescu, Andrei Daniela, \& Kruzslicika, 2015). Rural youth enter the work of agribusiness in response to rural needs that are 
clearly felt coupled with the tangible benefits of modern agricultural and agribusiness opportunities (Haggblade et al., 2015) and livelihood transition of farm households influenced by nonfarm households (Bhandari, 2013). Furthermore, rural areas provided wide spaces for the fast increasing urban capital and had comparative advantage in small-scale life (Kuhmonen, Kuhmonen, \& Luoto, 2016; J. Liu, Liu, \& Yan, 2016). However, rural businesses exit the market mainly due to lack of profitability or finance (Nagler \& Naudé, 2017), while social connections are critical to find business opportunities and obtain investment capital (Tian, Guo, \& Zheng, 2016).

Human and physical capitals, equipment provision, environmental income influences livelihood choice which is important to all livelihood strategies (Labao, Naval, Yap, \& Yap, 2017; Walelign \& Jiao, 2017; Wu, Li, \& Hou, 2017). Land access and education are crucial to young people to gain their goals in agriculture (Bezu \& Holden, 2014; Kidido, Bugri, \& Kasanga, 2017; Roudart \& Dave, 2017) where agro-climatic conditions are favorable in farming influence livelihood choice in agriculture (Davis, Di Giuseppe, \& Zezza, 2017). Meanwhile, major factors defining young people to migrate are household and individual level, bad infrastructure, general service factors and environmental conditions (Deotti, Laura; Estruch, 2016; Leibert, 2016; Qin \& Liao, 2016; Rauhut \& Littke, 2016; Wiest, 2016). Furthermore, the important factors which influences off-farm employment decisions are age and education, wage and crop prices (Henderson, 2005; Z. Liu \& Liu, 2016). And education become critical because it can helps to explain the wealth in agricultural households (Edirisinghe, 2015). The low education in rural regions would sharpen livelihood vulnerability of low income farmer and threaten the sustainable of household livelihoods (Wang et al., 2016).

In addition to increase welfare, livelihood improvement interventions with effective program implementation is needed, while regional policies which expand the opportunity space are needed to support the development and improvement of innovation systems to accelerate the creation of youth that can lead variety of agricultural employment activities (Fisher et al., 2017; Jiao, Pouliot, \& Walelign, 2017; Kararach, Hanson, \& Léautier, 2012; Martin \& Lorenzen, 2016; Steenbergen, Marlessy, \& Holle, 2017). Perceptions on individual household income express that the most participating young people considered higher production and intensiveness of harvesting (Oyedele \& Adenegan, 2017). Moreover, entrepreneurial skills are contribute in the stability of livelihood diversity behavior and decreasing of poverty (Fred M. Dzanku, 2015; Gautam \& Andersen, 2016). Increasing the farmers' income and also consider to the local institutional and non-institutional arrangements by improving infrastructure and water management sustains farmers to adopt different livelihood strategies to attaint their livelihood purposes (Bernier, Sultana, Bell, \& Ringler, 2016; MéndezLemus, Vieyra, \& Poncela, 2017; You \& Zhang, 2017). This study addresses the problem between livelihood choices and their determinants of rural youth.

\section{Research Methods}

This research was used survey data of young people in rural East Java, Indonesia with 200 rural young people respondents by random sampling based on Lemeshow, Hosmer Jr, Klar, \& Lwanga (1990) and it was conducted in 2017. This study was conducted in two regencies, Mojokerto and Ngawi that is not only classified as a rural area but also close to an industrial area in another city or district.

The force factors of livelihood option was analyzed by multinomial logit with random utility model (Maddala, 1983). Therefore, response probabilities for multinomial logit model of this study with four categories as follows,

$$
\operatorname{pr}\left(y=\frac{j}{x}\right)=\frac{\exp \left(X \beta_{j}\right)}{\left[1+\sum_{j=1}^{4} \exp \left(X \beta_{j}\right)\right]}, j=1, \ldots 4
$$

where $\mathrm{j}$ represents the alternative livelihoods including Agriculture; Non-agriculture employment; Entrepreneur in non-agriculture sector and Urban employment. $\mathrm{X}$ is a vector which represents factors that associate with the choice of livelihood of rural young people. The coefficients on the explanatory variables vary for each category. The factors which expected to impact livelihood option of young people include age, education, currently student, married status, farm size of parents, number of siblings in farm sector and number of siblings migrated. The hypotheses of this study is the availability of land for farming will become the reason of young people to choose agricultural livelihood.

\section{Results and Discussions}

\subsection{Main Characteristic of Sample}

Available online at HABITAT website: http://www.habitat.ub.ac.id ISSN: 0853-5167 (p); 2338-2007 (e) 
Table 1. provides information about the percentages of young people' education level both in Mojokerto and Ngawi Regencies with the total respondents of 200 people and illustrates about the percentages of married status, living together with parents, the averages of age and the amount of siblings in both regencies. The largest quantity of education level of youth was in elementary school by $38 \%$ and followed by junior high school which amounted for $33 \%$ and senior high school by 19.5 $\%$.

However, the lowest number of education level of young people in East Java was higher education. Moreover, only 16.5 respondents was married and $90.4 \%$ live with their parents with the average age of around 21 years old and also they have sibling around one to two.

Table 1. Main traits of sample

\begin{tabular}{lccc}
\hline & $\begin{array}{c}\text { Mojokerto } \\
\text { Regency }\end{array}$ & $\begin{array}{c}\text { Ngawi } \\
\text { Regency }\end{array}$ & All \\
\hline Sample size & 100 & 100 & 200 \\
\hline
\end{tabular}

\begin{tabular}{lccc}
\hline & $\begin{array}{c}\text { Mojokerto } \\
\text { Regency }\end{array}$ & $\begin{array}{c}\text { Ngawi } \\
\text { Regency }\end{array}$ & All \\
\hline \multicolumn{3}{c}{ Percentages (\%) } \\
\hline Education level & & 35 & 38 \\
\hline $\begin{array}{l}\text { Elementary } \\
\text { school }\end{array}$ & 41 & 35 & 33 \\
\hline $\begin{array}{l}\text { Junior high } \\
\text { school }\end{array}$ & 21 & 45 & 19.5 \\
\hline $\begin{array}{l}\text { Senior high } \\
\text { school }\end{array}$ & 27 & 12 & 9.5 \\
\hline $\begin{array}{l}\text { Higher } \\
\text { education }\end{array}$ & 11 & 8 & 16.5 \\
\hline Married & 22 & 11 & 90.5 \\
\hline $\begin{array}{l}\text { Live with } \\
\text { parents }\end{array}$ & 94 & 87 \\
\hline & Average & 21.16 & 21.29 \\
\hline Age & 21.41 & 1.82 & 1.96 \\
\hline $\begin{array}{l}\text { Number of } \\
\text { siblings }\end{array}$ & 2.1 & & \\
\hline
\end{tabular}

\subsection{Parent Characteristics}

Table 2. Parent Characteristics of Youth Sample in East Java

\begin{tabular}{lr}
\hline & Average (mean) \\
\hline Age of parent (year) & 51.69 \\
\hline Highest formal grade completed (year) & 7.90 \\
\hline Highest non-formal grade completed (year) & 0.06 \\
\hline Farming experience (year) & 23.60 \\
\hline Number of own children (person) & 3 \\
\hline Number of own children currently living with household (person) & 2 \\
\hline Number of member in household who involved in farming activity (person) & 2 \\
\hline Household income (IDR/year) & Percentages (\%) \\
\hline & 82.5 \\
\hline
\end{tabular}

On average, parents of male and female youth in research areas are over 50 years old and have been educated for almost 8 years. While the length of non-formal education is relatively small, less than 1 year. However, on average, the parents of the respondents have more than 20 years of farming experience with the number of family members working in the agricultural sector is 2 persons.

\subsection{Location Characteristics}

Table 3. Location Characteristics of Youth Respondents in East Java

\begin{tabular}{|c|c|c|c|c|c|}
\hline & \multicolumn{5}{|c|}{ Average (mean) } \\
\hline \multirow[t]{3}{*}{$\begin{array}{l}\text { Distance of respondent's house } \\
\text { location to city }(\mathrm{km})\end{array}$} & 14.88 & & & & \\
\hline & \multicolumn{5}{|c|}{ Percentages (\%) } \\
\hline & $\begin{array}{c}\text { Very } \\
\text { adequate }\end{array}$ & Adequate & $\begin{array}{c}\text { Quite } \\
\text { adequate }\end{array}$ & Inadequate & $\begin{array}{c}\text { Very } \\
\text { Inadequate }\end{array}$ \\
\hline
\end{tabular}




\begin{tabular}{lccccc}
\hline Irrigation & 18 & 55.5 & 13 & 10.5 & 3 \\
\hline Road access to market & 26.5 & 62 & 11 & 0.5 & 0 \\
\hline Transportation & 27.5 & 55 & 13.5 & 3 & 1 \\
\hline
\end{tabular}

The distance of respondent's house location to the city on average is almost $15 \mathrm{~km}$. The condition of agricultural irrigation infrastructure is considered adequate by $62 \%$, while $26.5 \%$ rate is sufficient thus there is no problem in irrigation infrastructure in the research area. Likewise with the access road to the market and transportation there are no obstacles, because the respondents rated both of infrastructure tend to be adequate.

\subsection{Farming Risk Characteristics}

Table 4. Farming Risk Characteristics of Youth Respondents in East Java

\begin{tabular}{lrrrrr}
\hline & \multicolumn{5}{c}{ Percentages (\%) } \\
\hline Risk of price fluctuations & Very large & Large & Quite large & Small & Very small \\
\hline Risk of marketing & 1.5 & 51 & 6 & 39.5 & 2 \\
\hline Risk of plant pests and diseases & 11.5 & 41 & 6.5 & 41 & 0 \\
\hline Risk of climate and weather & 1 & 42.5 & 7.5 & 48 & 1 \\
\hline
\end{tabular}

Some respondents considered that the risk of fluctuations in the selling price of food commodities tend to be very large $(51 \%)$, while others assess small (39.5\%). Respondents who already have clear market access tend to rate fluctuations in product prices tend to be small, but vice versa if the targeted market has not been determined, then the respondents feel the risk of fluctuations in product prices become very large. Marketing risk is considered small respondent because access road to market is considered adequate. In addition, climate and weather risks tend to be small for food commodities as well as the risks to plant pests and diseases.

\subsection{Livelihood Choice}

Table 5. Livelihood choice by male and female youth in East Java

Table 6 presents the results from multinomial logit model where agriculture sector is the reference livelihood category in presented model.

Table 6. Multinominal logit model of livelihood choice determinant factor by rural youth.

\begin{tabular}{|c|c|c|c|}
\hline Variables & $\begin{array}{l}\text { Non-agriculture } \\
\text { employment }\end{array}$ & $\begin{array}{l}\text { Entrepreneur in non- } \\
\text { agriculture sector }\end{array}$ & $\begin{array}{l}\begin{array}{l}\text { Urban } \\
\text { employment }\end{array} \\
\end{array}$ \\
\hline Age & -.0481 & $-.275(* *)$ & $-.522(* * * *)$ \\
\hline Education (year) & $.326(* * *)$ & $.366(* * *)$ & $.608(* * * *)$ \\
\hline Currently student & .137 & $-1.169(*)$ & -.149 \\
\hline Married status & -.043 & $1.103(*)$ & $1.749(* *)$ \\
\hline Farm size of parent (hectare) & $-1.469(* *)$ & $-1.720(* * *)$ & $-1.202(* *)$ \\
\hline Number of siblings in farm sector & $-.529(*)$ & $-.565(* *)$ & -.430 \\
\hline Number of siblings migrated & $1.170(* *)$ & .573 & $1.575(* * *)$ \\
\hline
\end{tabular}

Note: Agriculture is reference livelihood category. The declared values are coefficients followed by standard errors in parenthesis. Significance levels by $10 \%\left(^{*}\right), 5 \%(* *), 1 \%(* * *), 0.1 \%(* * * *)$ 
Age has consistently negative association with livelihood choice in outside of agriculture, but only significant with livelihood of entrepreneur in non-agriculture sector and urban employment. An increase in age decreases the likelihood of rural youth choosing a livelihood of entrepreneur in non-agriculture sector and urban employment over agriculture.

Education of youth has consistently positive and sharp association with livelihood choice which is outside of agricultural sector. An increase in education level increase the likelihood of rural youth selecting livelihood outside of agriculture. This seems to be influenced by the mind-set in the communities involved in agriculture, such factors are a less prestigious and decent choice, thus respondents who have a higher level of formal education tend to prefer decent work outside of agriculture.

The young people who currently learning in school are more possible to choose entrepreneur in non-agriculture sector than those who are no longer school pupils. This is probably because rural youth who are still in school have higher expectations of pursuing their purposes through educational way than rural youth who are no longer achieving education. More education increases the likelihood of choosing entrepreneur in non-agriculture sector.

Married status has positive and significant correlation with entrepreneur in non-agriculture sector and urban employment. Respondents who married are probably choosing urban employment as choice of livelihood, maybe because married youth have commitments to their family. Married status also has a negative relationship with entrepreneur in non-agriculture sector, although it is statistically significant only at $10 \%$.

Parent's land area variable has significant influence with negative coefficient. This represents that the larger land holding that rural youth's parents have, the lower possibility in choosing a livelihood outside of agriculture over farming and the land area owned by their parents. Meanwhile, the choice of young people as a child to participate in agricultural sector will be higher. There is a possibility that if rural youth's parents have more land possibilities for their children to get a piece of farming land will also be higher, so that it will motivate young people to choose livelihood in agricultural sector.

Number of siblings in farm sector has consistently negative association with choice of livelihood outside of agriculture, and statistically significant with non-agriculture employment and entrepreneur in non-agriculture sector. However only significant at $10 \%$ for livelihood option of non-agriculture employment. This may indicate that an increase in number of siblings in farm sector decreases the likelihood of respondent choosing entrepreneur in non-farm sector and nonagriculture employment. Rural youth tends to choose livelihood in agriculture if their siblings who work in farm sector are increase. Meanwhile, if number of siblings migrated increase, the livelihood option in urban employment and nonagriculture employment will increase. Young people who has more sibling works in other city tends to leave agriculture sector as their livelihood option.

\section{Conclusions}

Two major significant variables on youth decisions to choose in agricultural sector over other reference livelihood are education and land access. An increase in academic attainment increases the reasonable hopes of favourable outcome in outside farming relative to agriculture. But, an increase farming land which owned by parents decrease the possibility of young people to choose a livelihood outside of farming over agriculture. Therefore, agricultural sector will become significantly productive and competent to absorb the increasing labor force by making investment in sustainable agricultural technologies. And the private sector can also have a crucial position in facilitating the land access, finance and market of rural youth. Furthermore, the important policy implications related to youth in the agricultural sector are the support of sustainable rural investment in the form of infrastructure and increased investment in education.

\section{References}

Bernier, Q., Sultana, P., Bell, A. R., \& Ringler, C. (2016). Water management and livelihood choices in southwestern Bangladesh. Journal of Rural Studies, 45, 134-145. https://doi.org/10.1016/j.jrurstud.2015.12.0 17

Bezu, S., \& Holden, S. (2014). Are rural youth in ethiopia abandoning agriculture? World Development, 64, 259-272. https://doi.org/10.1016/j.worlddev.2014.06 .013 
Bhandari, P. B. (2013). Rural livelihood change? Household capital, community resources and livelihood transition. Journal of Rural Studies, 32, 126-136. https://doi.org/10.1016/j.jrurstud.2013.05.0 01

Chiritescu, V., Andrei Daniela, R., \& Kruzslicika, M. (2015). the Role of Youth in Sustainable Development of Romanian Rural Communities. Romanian Economic and Business Review, 10(2), 183-197.

Davis, B., Di Giuseppe, S., \& Zezza, A. (2017). Are African households (not) leaving agriculture? Patterns of households' income sources in rural Sub-Saharan Africa. Food Policy, 67, 153-174. https://doi.org/10.1016/j.foodpol.2016.09.0 18

Deotti, Laura; Estruch, E. (2016). Addressing rural youth migration at its root causes: A conceptual framework. Retrieved from http://www.fao.org/3/a-i5718e.pdf

Dzanku, F. M. (2015). Transient rural livelihoods and poverty in Ghana. Journal of Rural Studies, $\quad 40$, 102-110. https://doi.org/10.1016/j.jrurstud.2015.06.0 09

Edirisinghe, J. C. (2015). Smallholder farmers' household wealth and livelihood choices in developing countries: A Sri Lankan case study. Economic Analysis and Policy, 45, 33-38.

https://doi.org/10.1016/j.eap.2015.01.001

Fisher, E., Attah, R., Barca, V., O'Brien, C., Brook, S., Holland, J., ... Pozarny, P. (2017). The Livelihood Impacts of Cash Transfers in Sub-Saharan Africa: Beneficiary Perspectives from Six Countries. World Development, 99, 299319.

https://doi.org/10.1016/j.worlddev.2017.05 .020

Gregoire, C. (2011). An identification of selected environmentally based livelihood issues within the Caribbean. World Journal of Science, Technology and Sustainable Development, $8(1)$. https://doi.org/https://doi.org/10.1108/2042 5945201100005 Permanent

Haggblade, S., Chapoto, A., Drame-Yayé, A., Hendriks, S. L., Kabwe, S., Minde, I., ...
Terblanche, S. (2015). Motivating and preparing African youth for successful careers in agribusiness. Journal of Agribusiness in Developing and Emerging Economies, 5(2), 170-189. https://doi.org/10.1108/JADEE-01-20150001

Henderson, R. (2005). Education, training and rural living: Young people in Ryedale. Education and Training, 47(3), 183-201. https://doi.org/10.1108/004009105105922 39

Jiao, X., Pouliot, M., \& Walelign, S. Z. (2017). Livelihood Strategies and Dynamics in Rural Cambodia. World Development, 97, 266-278. https://doi.org/10.1016/j.worlddev.2017.04 .019

Kararach, G., Hanson, K. T., \& Léautier, F. A. (2012). Regional Integration Policies to Support Job Creation for Africa's Burgeoning Youth Population. World Journal of Entrepreneurship, Management and Sustainable Development, 7(2/3/4), 177-215. https://doi.org/https://doi.org/10.1108/2042 5961201000035

Kidido, J. K., Bugri, J. T., \& Kasanga, R. K. (2017). Dynamics of youth access to agricultural land under the customary tenure regime in the Techiman traditional area of Ghana. Land Use Policy, 60, 254266.

https://doi.org/10.1016/j.landusepol.2016.1 0.040

Kuhmonen, T., Kuhmonen, I., \& Luoto, L. (2016). How do rural areas profile in the futures dreams by the Finnish youth? Journal of Rural Studies, 44, 89-100. https://doi.org/10.1016/j.jrurstud.2016.01.0 10

Labao, A. B., Naval, P. C., Yap, D. L. T., \& Yap, H. T. (2017). Influencing rural livelihood switching through equipment assets for agroecosystems to alleviate pressure on resources. Agriculture, Ecosystems and Environment, 248(July), 96-104. https://doi.org/10.1016/j.agee.2017.07.016

Leibert, T. (2016). She leaves, he stays? Sexselective migration in rural East Germany. Journal of Rural Studies, 43, 267-279. 
https://doi.org/10.1016/j.jrurstud.2015.06.0 04

Lemeshow, S., Hosmer Jr, D. W., Klar, J., \& Lwanga, S. K. (1990). Adequacy of Sample Size in Health Studies. Adequacy of Sample Size in Health Studies. John Wiley \& Sons Ltd. https://doi.org/10.1186/1472-6963-14335

Liu, J., Liu, Y., \& Yan, M. (2016). Spatial and temporal change in urban-rural land use transformation at village scale-A case study of Xuanhua district, North China. Journal of Rural Studies, 47, 425-434. https://doi.org/10.1016/j.jrurstud.2016.07.0 03

Liu, Z., \& Liu, L. (2016). Characteristics and driving factors of rural livelihood transition in the east coastal region of China: A case study of suburban Shanghai. Journal of Rural Studies, 43, 145-158. https://doi.org/10.1016/j.jrurstud.2015.12.0 08

Maddala, G. . (1983). Limited-dependent and Quantitative Variables in Econometrics. Cambridge University Press.

Martin, S. M., \& Lorenzen, K. (2016). Livelihood Diversification in Rural Laos. World Development, 83, 231-243. https://doi.org/10.1016/j.worlddev.2016.01 .018

Méndez-Lemus, Y., Vieyra, A., \& Poncela, L. (2017). Periurbanization, Agricultural Livelihoods and Ejidatarioś Social Capital: Lessons from a Periphery Municipality in Michoacán, Mexico. Procedia Engineering, 198(September 2016), 428-443. https://doi.org/10.1016/j.proeng.2017.07.0 98

Ministry of Agriculture Republic Indonesia. (2015). Renstra Kementrian Pertanian Pertanian Tahun 2015 - 2019. Kementrian Pertanian. https://doi.org/351.077 Ind r

Nagler, P., \& Naudé, W. (2017). Non-farm entrepreneurship in rural sub-Saharan Africa: New empirical evidence. Food Policy, 67, 175-191. https://doi.org/10.1016/j.foodpol.2016.09.0 19

Oyedele, O. A., \& Adenegan, K. O. (2017). Impact of the production of underutilized vegetables on the livelihood of farmers in Southwestern Nigeria. International Journal of Social Economics, 44(12), 1669-1682. https://doi.org/https://doi.org/10.1108/IJSE -03-2016-0081

Qian, W., Wang, D., \& Zheng, L. (2016). The impact of migration on agricultural restructuring: Evidence from Jiangxi Province in China. Journal of Rural Studies, 47, 542-551. https://doi.org/10.1016/j.jrurstud.2016.07.0 24

Qiao, Y., Martin, F., Cook, S., He, X., Halberg, N., Scott, S., \& Pan, X. (2018). Certified Organic Agriculture as an Alternative Livelihood Strategy for Small-scale Farmers in China: A Case Study in Wanzai County, Jiangxi Province. Ecological Economics, 145(October 2017), 301-307. https://doi.org/10.1016/j.ecolecon.2017.10. 025

Qin, H., \& Liao, T. F. (2016). Labor out-migration and agricultural change in rural China: A systematic review and meta-analysis. Journal of Rural Studies, 47, 533-541. https://doi.org/10.1016/j.jrurstud.2016.06.0 20

Rauhut, D., \& Littke, H. (2016). "A one way ticket to the city, please!" on young women leaving the Swedish peripheral region Västernorrland. Journal of Rural Studies, 43, 301-310. https://doi.org/10.1016/j.jrurstud.2015.05.0 03

Roudart, L., \& Dave, B. (2017). Land policy, family farms, food production and livelihoods in the Office du Niger area, Mali. Land Use Policy, 60, 313-323. https://doi.org/10.1016/j.landusepol.2016.1 0.029

Smith, H. E., Hudson, M. D., \& Schreckenberg, K. (2017). Livelihood diversification: The role of charcoal production in southern Malawi. Energy for Sustainable Development, 36, 22-36. https://doi.org/10.1016/j.esd.2016.10.001

Steenbergen, D. J., Marlessy, C., \& Holle, E. (2017). Effects of rapid livelihood transitions: Examining local co-developed change following a seaweed farming boom. Marine Policy, 82(March), 216-223. 
https://doi.org/10.1016/j.marpol.2017.03.0

26

Tang, Q., Bennett, S. J., Xu, Y., \& Li, Y. (2013). Agricultural practices and sustainable livelihoods: Rural transformation within the Loess Plateau, China. Applied Geography, 41 , $15-23$. https://doi.org/10.1016/j.apgeog.2013.03.0 07

Tian, Q., Guo, L., \& Zheng, L. (2016). Urbanization and rural livelihoods: A case study from Jiangxi Province, China. Journal of Rural Studies, 47, 577-587. https://doi.org/10.1016/j.jrurstud.2016.07.0 15

Walelign, S. Z., \& Jiao, X. (2017). Dynamics of rural livelihoods and environmental reliance: Empirical evidence from Nepal. Forest Policy and Economics, 83(May 2016), 199-209. https://doi.org/10.1016/j.forpol.2017.04.00 8

Wang, C., Zhang, Y., Yang, Y., Yang, Q., Kush, J., Xu, Y., \& Xu, L. (2016). Assessment of sustainable livelihoods of different farmers in hilly red soil erosion areas of southern China. Ecological Indicators, 64, 123-131. https://doi.org/10.1016/j.ecolind.2015.12.0 36

Wiest, K. (2016). Migration and everyday discourses: Peripheralisation in rural Saxony-Anhalt from a gender perspective. Journal of Rural Studies, 43, 280-290. https://doi.org/10.1016/j.jrurstud.2015.03.0 03

Wu, Z., Li, B., \& Hou, Y. (2017). Adaptive choice of livelihood patterns in rural households in a farm-pastoral zone: A case study in Jungar, Inner Mongolia. Land Use Policy, 62, 361-375. https://doi.org/10.1016/j.landusepol.2017.0 1.009

You, H., \& Zhang, X. (2017). Sustainable livelihoods and rural sustainability in China: Ecologically secure, economically efficient or socially equitable? Resources, Conservation and Recycling, 120, 1-13. https://doi.org/10.1016/j.resconrec.2016.12 .010 